Georgia State University

ScholarWorks @ Georgia State University

\title{
North Carolina Hispanic Farmworkers and Intestinal Parasitism: A Pilot Study of Prevalence and Health-Related Practices,and Potential Means of Foodborne Transmission
}

\author{
Mindi Russell \\ North Carolina State Laboratory of Public Health \\ Maria Correa \\ North Carolina State University at Raleigh \\ Christine E. Stauber \\ Georgia State University \\ Julie Case \\ United States Food and Drug Administration
}

Follow this and additional works at: https://scholarworks.gsu.edu/iph_facpub

Part of the Public Health Commons

\section{Recommended Citation}

Russell, M.D., M.T. Correa, C.E. Stauber, and J.A. Kase. 2010. North Carolina Hispanic Farm Workers and Intestinal Parasitism: A Pilot Study of Prevalence and Health-Related Practices, and a Potential Means of Foodborne Transmission. Journal of Food Protection, Vol. 73, No. 5, 2010 p. 985-988.

This Article is brought to you for free and open access by the School of Public Health at ScholarWorks @ Georgia State University. It has been accepted for inclusion in Public Health Faculty Publications by an authorized administrator of ScholarWorks @ Georgia State University. For more information, please contact scholarworks@gsu.edu. 


\title{
Research Note
}

\section{North Carolina Hispanic Farmworkers and Intestinal Parasitism: A Pilot Study of Prevalence and Health-Related Practices, and Potential Means of Foodborne Transmission}

\author{
MINDI D. RUSSELL, ${ }^{1 \dagger}$ MARIA T. CORREA, ${ }^{2}$ CHRISTINE E. STAUBER,${ }^{3}$ AND JULIE A. KASE ${ }^{1 *}$ \\ ${ }^{1}$ North Carolina State Laboratory of Public Health, Raleigh, North Carolina 27601; ${ }^{2}$ North Carolina State University, College of Veterinary Medicine, \\ Raleigh, North Carolina 27695; and ${ }^{3}$ Georgia State University, Institute of Public Health, Atlanta, Georgia 30302, USA
}

MS 09-406: Received 25 September 2009/Accepted 30 December 2009

\begin{abstract}
Migrant and seasonal farmworkers provide much of the necessary labor to harvest and process agricultural commodities desired by consumers. Little is known about the health status (especially the parasitic burden) of farm laborers, who handpick agricultural items such as fruits and vegetables, despite being implicated as a means of foodborne pathogen transmission. The goal of this research was to develop a framework to investigate enteric parasitic infections among Hispanic farmworkers in Eastern North Carolina. Seventy-one interviews were conducted, 16 stool samples were collected, and two parasite-positive workers were found. In addition, some potentially harmful health practices (e.g., self-medication) were identified. Further research is necessary to fully understand the scope of farmworker health issues and the potential risk of disseminating foodborne pathogens to humans. The study model presented provides a geographically expandable format to allow for various types of health investigations including the prevalence of other pathogens.
\end{abstract}

Enteric parasites cause human illness with key routes of transmission being direct and indirect contact with fecally contaminated food or water. Contamination of food can occur at many points along the food production and processing continuum with ill farmworkers playing a potentially important role in transmission. For example, Guatemalan raspberries were implicated in a large outbreak of cyclosporiasis in 1996. Certain farm-related practices (e.g., use of contaminated water to mix insecticide and/or fungicide and direct contact between workers' hands and berries as the fruit were picked and sorted) were identified as possible means of Cyclospora transmission on multiple farms (6). In the case of the cyclosporiasis outbreak of 1996, humans are thought to have been the only source of Cyclospora oocysts, and surveillance activities conducted the following spring found several Guatemalan raspberry workers infected with Cyclospora, most of them asymptomatically (5). Approximately $85 \%$ of fruits and vegetables produced in the United States are harvested by hand, and the intensive processes of harvesting and premarket handling (e.g., lettuce coring)

\footnotetext{
* Author for correspondence. Present address: Microbial Methods Development Branch, Division of Microbiology, Office of Regulatory Sciences, Center for Food Safety and Applied Nutrition, U.S. Food and Drug Administration, 5100 Paint Branch Parkway, Room 3E-023, HFS711, College Park, MD 20740, USA. Tel: 301-436-2923; Fax: 301-4362329; E-mail: julie.kase@fda.hhs.gov.

$\dagger$ Present address: Microbial Methods Development Branch, Division of Microbiology, Office of Regulatory Sciences, Center for Food Safety and Applied Nutrition, U.S. Food and Drug Administration, 5100 Paint Branch Parkway, HFS-711, College Park, MD 20740, USA.
}

provide numerous opportunities for human contact (8). Ingestion of parasites through contaminated foods that are minimally processed or consumed raw is of particular concern since preparatory measures (e.g., cooking) that may reduce or eliminate parasites are often bypassed.

In 2002, North Carolina (NC) had the fifth largest farmworker population (approximately 108,900) in the United States (11). Studies have found that migrant and seasonal farmworkers have poorer physical health than the general population due to occupational hazards and inadequate living conditions (11). A population-based study conducted in 1987 reported that workers in $\mathrm{NC}$ had parasite prevalence rates ranging from 20 to $80 \%$. Parasites identified included helminths (e.g., Ascaris lumbricoides), protozoans (e.g., Giardia lamblia), and nonpathogens (e.g., Entamoeba coli) (4). Decades later, this population has grown $394 \%$, yet neither a health update nor a framework for migrant health surveillance exists (12).

Our objective was to implement a pilot study, involving collaboration with local community health centers that serve migrant communities, to determine the prevalence of intestinal parasitism, identify health-related practices, and highlight potential dissemination routes of foodborne pathogens with respect to Hispanic migrant and seasonal farmworkers in Eastern NC during the 2007 planting and harvesting season.

\section{MATERIALS AND METHODS}

Terms. "Hispanic" describes those persons originating from Mexico, or Central or South America. "Migrant or seasonal 
farmworker' is a person who is or has been employed in hand labor operations the majority of the time and/or who has changed residence for purposes of employment in agriculture. The term " $\mathrm{H}$ $2 \mathrm{~A}$ worker" is a worker with a visa to work seasonally in agriculture. "Latrines" are commonly used in developing countries as a more hygienic alternative to open defecation and characteristically consist of multiple toilets with no running water for flushing. Waste is collected and undergoes decomposition within a pit dug into the ground. "Portable bathrooms", are selfcontained, single-toilet, free-standing structures designed to be drained and cleaned on a regular basis. They are often used as temporary toilets for large public gatherings or on work sites.

Participants. Study participants were recruited on a volunteer basis through three collaborating $\mathrm{NC}$ community health centers. Criteria for eligibility included the following: (i) adult status (at least 18 years of age); (ii) self-reported Hispanic ethnicity; and (iii) classification as $\mathrm{H}-2 \mathrm{~A}$, migrant, or seasonal farmworker.

Questionnaire. Questionnaires were verbally administered in Spanish and documented characteristics including demographics, occupation, lifestyle (e.g., household size, availability of sanitation facilities, and hygienic practices), and self-medicating practices (self-reported intake of medications used specifically to treat parasitic infections). To maintain confidentiality, questionnaires were numerically coded. EpiInfo was used for data entry and descriptive analysis (1).

Stool specimens. Participants who completed the questionnaire were also asked to provide a stool sample. Those who agreed were provided with a sample collection kit (specimen containers, newspaper, gloves, alcohol wipes, and a plastic bag), detailed verbal instructions, and brochures in Spanish on the proper collection procedure. Stool samples were retrieved approximately 1 week following the initial visit. Ova and parasite examinations were performed at the NC State Laboratory of Public Health (2). The NC State Laboratory of Public Health is a certified reference laboratory routinely receiving reference specimens for confirmation of intestinal parasitic worms and protozoa. All test results were reported to participants through the community health centers.

\section{RESULTS}

Respondent characteristics. Of the 71 farmworkers surveyed from 25 camps in five counties, 55 (77.5\%) were aged between 20 and 40 years, with a median age of 27 years. The majority $(86 \%)$ were men, with $96 \%$ born in Mexico. Forty-three $(61 \%)$ worked one primary job, 26 (37\%) worked two jobs, and $1(1 \%)$ worked three jobs during the harvesting season. Most worked on tobacco $(73 \%)$ and/or produce $(51 \%)$ farms between April and September 2007. All workers shared living quarters with four to six people. Comparison of sanitation facility availability at home (versus work) found that $75 \%(27 \%)$ used private toilets, $7 \%(11 \%)$ used latrines, and 7\% (41\%) used portable bathrooms. Workers reported washing their hands after using the bathroom at home $(90 \%)$ and work $(73 \%)$ and before cooking (89\%). Affliction with parasitism during childhood was reported by $38 \%$ of workers, and $3 \%$ reported testing positive for intestinal parasites in the United States. Thirty-four percent reported intake of specific medication to treat parasitic infection. Data are presented in Table 1.
Parasitism in the studied population. Fifty-two collection kits were distributed, and 16 stool samples were analyzed. Intestinal parasites were recovered from two individuals, with a proportion of infection of $12.5 \%$. Single-species parasitic infection was reported among the two cases for either G. lamblia or E. coli. The infected cases were men between the ages of 33 and 45 years, foreign-born in Mexico, working with one or more food crop, traveling between Mexico and the United States on a yearly basis, and self-medicating for parasitic infections before entering the United States.

\section{DISCUSSION}

Inherent complexities exist when conducting migrant worker health studies including (i) the transient and inaccessible nature of the population; (ii) documentation of workers or lack thereof; and (iii) sensitivities related to study requirements (i.e., stool collection). We were able to overcome these barriers by partnering with community health centers, and more specifically, integrating ourselves with migrant outreach teams that provided certain free services (e.g., blood pressure checks and rapid human immunodeficiency virus tests). Importantly, this framework is geographically expandable and flexible enough to allow for various types of health investigations including the prevalence of other pathogens. While monetary compensation would have encouraged a greater response rate, providing rewards (e.g., items donated to the project such as hats, gloves, and hygiene products) for survey completion was effective.

In addition to providing data on prevalence, this study identified areas of public health concern. Self-medication for symptoms of parasitism occurred among 34\% of workers. Medication may include both prescription and nonprescription products obtained in Mexican pharmacies. A recently published study found that $30 \%$ of Latinos surveyed acknowledged carrying antibiotics, herbal medication, and other medicine into the United States from other countries (10). Respondents in our study did not always recall the specific name of their medication, but many indicated taking Vermox (mebendazole), a broad-spectrum antihelminthic medication not recommended for the treatment of intestinal protozoan parasites. Workers reported taking doses, with or without symptoms, before leaving Mexico and while in the United States. However, it was not clear if the medicine was being stored or taken properly, i.e., at the correct dosage and frequency, leading to concerns of efficacy, safety, and the development of drug resistance.

Additionally, this study identified workers infected with a parasite implicated in past foodborne outbreaks, $G$. lamblia. For instance, outbreaks of giardiasis associated with vegetables and lettuce-based salads were reported in 2005 and 2007 causing a total of 65 illnesses (3). Infected food handlers are very often implicated in giardiasis outbreaks, suggesting the ease of foodborne transmission. For example, an infected food handler preparing raw vegetables that were later served in an office cafeteria was the probable cause of nearly 30 cases (7).

Raw produce typically undergoes minimal postharvest treatment and may be packed immediately after picking, thus 
TABLE 1. Characteristics of Hispanic farmworkers in eastern North Carolina

\begin{tabular}{|c|c|c|c|}
\hline \multirow[b]{3}{*}{ Characteristic } & \multicolumn{3}{|c|}{$\begin{array}{c}\text { No. }(\%) \text { of farmworkers with indicated } \\
\text { characteristic }\end{array}$} \\
\hline & \multirow[b]{2}{*}{$\begin{array}{l}\text { All farmworkers } \\
\quad(n=71)\end{array}$} & \multicolumn{2}{|c|}{$\begin{array}{l}\text { Subset with worker } \\
\text { status: }\end{array}$} \\
\hline & & $\begin{array}{c}\text { H-2A } \\
(n=29)\end{array}$ & $\begin{array}{c}\text { Non-H-2A } \\
(n=42)\end{array}$ \\
\hline \multicolumn{4}{|l|}{ Demographics } \\
\hline \multicolumn{4}{|l|}{ Age (yr) } \\
\hline$<20$ & $8(11.4)$ & $3(10.3)$ & $5(11.9)$ \\
\hline $21-30$ & $31(44.3)$ & $13(44.8)$ & $18(42.9)$ \\
\hline $31-40$ & $24(34.3)$ & $10(34.5)$ & $14(33.3)$ \\
\hline $41-50$ & $4(5.8)$ & $3(10.3)$ & $1(2.4)$ \\
\hline$>50$ & $1(1.4)$ & $0(0)$ & $1(2.4)$ \\
\hline Missing $^{a}$ & $3(4.2)$ & $0(0)$ & $3(7.1)$ \\
\hline \multicolumn{4}{|l|}{ Gender } \\
\hline Male & $61(86.0)$ & $29(100)$ & $32(76.2)$ \\
\hline Female & $10(14.0)$ & $0(0)$ & $10(23.8)$ \\
\hline \multicolumn{4}{|l|}{ Birth country } \\
\hline Mexico & $68(95.8)$ & $28(96.6)$ & $40(95.2)$ \\
\hline United States & $2(2.8)$ & $1(3.4)$ & $1(2.4)$ \\
\hline Missing & $1(1.4)$ & $0(0)$ & $1(2.4)$ \\
\hline \multicolumn{4}{|l|}{ Occupation } \\
\hline \multicolumn{4}{|l|}{ No. of crops/jobs } \\
\hline One & $43(61)$ & $19(65.5)$ & $24(57.1)$ \\
\hline Two & $26(37)$ & $10(34.5)$ & $16(38.1)$ \\
\hline Three or more & $1(1)$ & $0(0)$ & $1(2.4)$ \\
\hline Missing & $1(1)$ & $0(0)$ & $0(0)$ \\
\hline \multicolumn{4}{|l|}{ Type of work ${ }^{b}$} \\
\hline $\begin{array}{l}\text { Fruits and } \\
\text { vegetables }\end{array}$ & $36(50.7)$ & $9(31)$ & $27(64.3)$ \\
\hline Tobacco & $52(73.2)$ & $26(89.7)$ & $26(61.9)$ \\
\hline Construction & $5(7.0)$ & $2(6.9)$ & $3(7.1)$ \\
\hline Pork (swine) & $1(1.4)$ & $0(0)$ & $1(2.4)$ \\
\hline Beef & $0(0)$ & $0(0)$ & $0(0)$ \\
\hline Poultry & $0(0)$ & $0(0)$ & $0(0)$ \\
\hline \multicolumn{4}{|l|}{ Lifestyle } \\
\hline \multicolumn{4}{|c|}{ Sanitation facilities at home } \\
\hline Private & $53(74.6)$ & $25(86.2)$ & $28(66.8)$ \\
\hline Latrine & $5(7.0)$ & $2(6.9)$ & $3(7.1)$ \\
\hline Portable & $5(7.0)$ & $2(6.9)$ & $3(7.1)$ \\
\hline Missing & $8(11.4)$ & $0(0)$ & $8(19.0)$ \\
\hline \multicolumn{4}{|c|}{ Sanitation facilities at work } \\
\hline Private & $19(26.8)$ & $3(10.3)$ & $16(38.1)$ \\
\hline Latrine & $8(11.3)$ & $5(17.3)$ & $3(7.1)$ \\
\hline Portable & $29(40.8)$ & $17(58.6)$ & $12(28.6)$ \\
\hline Missing & $15(21.1)$ & $4(13.8)$ & $11(26.2)$ \\
\hline \multicolumn{4}{|l|}{ Hand washing } \\
\hline \multicolumn{4}{|c|}{ After bathroom at home } \\
\hline Yes & $64(90)$ & $29(100)$ & $35(83)$ \\
\hline \multicolumn{4}{|c|}{ After bathroom at work } \\
\hline Yes & $52(73.3)$ & $24(82.8)$ & $28(66.7)$ \\
\hline \multicolumn{4}{|c|}{ Before preparing food } \\
\hline Yes & $63(88.7)$ & $24(82.8)$ & $39(92.9)$ \\
\hline
\end{tabular}

TABLE 1. Continued

\begin{tabular}{|c|c|c|c|}
\hline \multirow[b]{3}{*}{ Characteristic } & \multicolumn{3}{|c|}{$\begin{array}{c}\text { No. }(\%) \text { of farmworkers with indicated } \\
\text { characteristic }\end{array}$} \\
\hline & \multirow[b]{2}{*}{$\begin{array}{l}\text { All farmworkers } \\
\quad(n=71)\end{array}$} & \multicolumn{2}{|c|}{$\begin{array}{l}\text { Subset with worker } \\
\text { status: }\end{array}$} \\
\hline & & $\begin{array}{c}\mathrm{H}-2 \mathrm{~A} \\
(n=29)\end{array}$ & $\begin{array}{l}\text { Non-H-2A } \\
(n=42)\end{array}$ \\
\hline \multicolumn{4}{|c|}{ Self-medicating practices } \\
\hline \multicolumn{4}{|l|}{ Self-reported intake } \\
\hline Yes & $24(33.8)$ & $10(34.5)$ & $14(33.3)$ \\
\hline No/missing & $47(66.2)$ & $19(65.5)$ & $28(66.7)$ \\
\hline
\end{tabular}

${ }^{a}$ Missing refers to data that were not provided by respondents.

${ }^{b}$ Data are nonexclusive; respondents were allowed to answer more than one choice.

bypassing critical control steps used to mitigate potential foodborne pathogens. Importantly, G. lamblia is not killed by chlorine levels typically used to rinse produce postharvest, and the organism is especially difficult to wash off complex food surfaces (9). The transfer of parasites to food via fecally contaminated hands (e.g., picking, sorting, and packing produce by hand), field implements (e.g., lettuce corer), irrigation water, or potable water used for washing food items prior to packaging for transport are potential ways transmissible stages of parasites can be disseminated.

Factors such as availability of sanitation facilities and inadequate personal hygiene may enhance the transmission and increase the risk of parasitic infection among farmworkers. While a majority of workers $(68 \%)$ reported access to toilets while working, only $73 \%$ stated washing their hands prior to returning to work. Several explanations for this small discrepancy exist including the possibility of stand-alone hand washing facilities without access to toilets, the overreporting of good hygiene, and possible misinterpretation of the question by the interviewee. While field sanitation requirements exist in NC (29 CFR 1928.110) stating that workers must be provided with hand washing facilities and toilets, follow-up is needed to determine why a higher percentage of workers reported washing hands at home $(90 \%)$. More emphasis should be placed on worker outreach activities that promote good hygienic practices and stress the important role that farmworkers play in food safety and in reducing the risk of transmission of foodborne parasites from agricultural commodities to consumers.

\section{ACKNOWLEDGMENTS}

This research was supported in part by an appointment (M. D. Russell) to the Emerging Infectious Diseases (EID) Fellowship Program administered by the Association of Public Health Laboratories (APHL) and funded by the Centers for Disease Control and Prevention (CDC). This project would not have been possible without the interviewers, especially Margaret Jackson, the outreach staff at the three collaborating community health centers, and the study participants. We express our deepest gratitude to them and also to Dr. LeeAnn Jaykus for her critical review of the manuscript. Human participant protection: This study was approved by the Institutional Review Board at North Carolina State University. The study was also approved by the board members of each collaborating community health center. 


\section{REFERENCES}

1. Centers for Disease Control and Prevention. Epidemiology software application. Available at: http://www.fruitsandveggiesmorematters. gov/epiinfo/. Accessed 10 March 2007.

2. Centers for Disease Control and Prevention. Diagnostic proceduresstool specimens. Available at: http://www.dpd.cdc.gov/dpdx/HTML/ DiagnosticProcedures.htm. Accessed 15 October 2006.

3. Centers for Disease Control and Prevention. Annual listing of foodborne disease outbreaks, United States, U.S. Department of Health and Human Services. Available at http://www.cdc.gov/ foodborneoutbreaks/outbreak_data.htm. Accessed 4 December 2009.

4. Ciesielski, S. D., J. R. Seed, J. C. Ortiz, and J. Metts. 1992. Intestinal parasites among North Carolina migrant farmworkers. Am. J. Public Health 82:1258-1262.

5. Herwaldt, B. L. 2000. Cyclospora cayetanensis: a review, focusing on the outbreaks of cyclosporiasis in the 1990s. Clin. Infect. Dis. 31:1040-1057.

6. Herwaldt, B. L., M.-L. Ackers, and the Cyclospora Working Group. 1997. An outbreak in 1996 of cyclosporiasis associated with imported raspberries. N. Engl. J. Med. 336:1548-1556.
7. Mintz, E. D., M. Hudson-Wragg, P. Mshar, M. L. Cartter, and J. L. Hadler. 1993. Foodborne giardiasis in a corporate office setting. $J$. Infect. Dis. 167:250-253.

8. Oliveira, V., J. R. Effland, and S. Hamm. 1993. Hired farm labor use on fruit, vegetable, and horticultural specialty farms. U.S. Department of Agriculture, Economic Research Service, Washington, DC.

9. Sivapalasingam, S., C. R. Friedman, L. Cohen, and R. V. Tauxe. 2004. Fresh produce: a growing cause of outbreaks of foodborne illness in the United States, 1973 through 1997. J. Food Prot. 67: 2342-2353.

10. Sleath, B., S. J. Blalock, D. Bender, M. Murray, A. Cerna, and M. G. Cohen. 2009. Latinos' sources of medication and medication information in the United States and their home countries. Patient Educ. Couns. 75:279-282.

11. Triantafillou, S. A. 2003. North Carolina's migrant and seasonal farmworkers. N.C. Med. J. 64:129-132.

12. U.S. Census Bureau. 2001. Hispanic or latino origin: all races. Mapping census 2000: the geography of US diversity. Available at: www.census.gov/population/www/cen2000/dt_atlas.html. Accessed 15 June 2008. 
Reproduced with permission of the copyright owner. Further reproduction prohibited without permission. 